\title{
Hemochromatoza pierwotna - wykorzystanie krwi pochodzącej z leczniczych krwioupustów do celów klinicznych
}

\author{
Hereditary hemochromatosis - therapeutic phlebotomy as additional \\ source of blood
}

\author{
Aleksandra Rosiek@
}

Zakład Transfuzjologii Instytutu Hematologii i Transfuzjologii w Warszawie

\begin{abstract}
Streszczenie
$W$ wielu krajach obserwuje sie obecnie spadek liczby krwiodawców, a w konsekwencji zmniejszenie zasobów krwi i jej sktadników przeznaczonych do celów klinicznych. Jednym $z$ dziatan podejmowanych $w$ celu poprawy sytuacji jest dopuszczenie do oddawania krwi osób z rozpoznana hemochromatoza pierwotna - uwarunkowana genetycznie choroba, której nastęstwem jest zespót przeciażenia żelazem. Najbardziej efektywny sposób jej leczenia opiera sie na wykonywaniu czestych krwioupustów w celu eliminacji z organizmu nadmiaru żelaza.
\end{abstract}

Krew pochodzaca z leczniczych krwioupustów jest czesto niszczona. Obawy zwiazane z jej wykorzystywaniem do celów klinicznych dotyczq przede wszystkim dodatkowych czynników wplywajacych na bezpieczeństwo tak pozyskanych sktadników krwi, brak jednak obecnie przekonujacych dowodów na zwiększenie zagrożenia dla biorców otrzymujacych krew od dawców $z$ HH. Podnoszone sa także zastrzeżenia odnoszace się do problemów organizacyjnych i kosztów oraz watpliwości natury etycznej dotyczace dobrowolności donacji.

W Polsce - zgodnie z aktualnie obowiqzujacymi przepisami — osoby z HH nie moga oddawać krwi w czasie wystęowania objawów choroby, a także w trakcie stosowanego leczenia innego niz krwioupusty. O możliwości oddania krwi oraz czestotliwości kolejnych donacji decyduje lekarz w jednostce organizacyjnej publicznej stuzby krwi, w porozumieniu z lekarzem prowadzacym leczenie hemochromatozy.

Zasady postępowania wobec tej grupy potencjalnych krwiodawców w innych krajach charakteryzuja sie znacznym zróżnicowaniem. W wielu opracowaniach podkreśla sie obecnie potrzebe opracowania — na podstawie wyników dostepnych badań — jednolitych, optymalnych zasad postepowania.

\section{Słowa kluczowe: krwiodawstwo, krwiodawcy, hemochromatoza}

J. Transf. Med. 2019; 12: 65-71

\begin{abstract}
Many countries currently witness a decline in the number of blood donors and, consequently, a decrease in supply of blood and blood components dedicated for clinical use. To improve the situation one of the measures taken is to qualify for blood donation people with diagnosed
\end{abstract}


hereditary hemochromatosis $(H H)$ - a genetic disorder that leads to iron overload, most effectively treated by frequent bloodletting to eliminate the excess of iron.

Blood from therapeutic phlebotomy is often discarded. Reservations and doubts related to the clinical use of this blood are primarily related to additional factors that affect its safety. However, there is currently no convincing evidence that blood from $\mathrm{HH}$ donors exposes recipients to higher risk. Reservations are also raised regarding organizational challenge and costs as well as ethical concerns regarding the voluntary nature of donations.

In Poland - according to current regulations - HH individuals are deferred from donating blood during the onset of disease symptoms or in the course of treatment other than phlebotomy. The decision regarding blood donation as well as frequency of subsequent donations is made by the physician in the unit of the public health service in cooperation with the doctor responsible for therapy of hemochromatosis.

Guidelines regarding this group of potential blood donors markedly differ from country to country therefore numerous publications emphasize the need to develop a set of uniform, optimal regulations based on the outcome of available research.

Key words: blood donation, blood donors, hemochromatosis

J. Transf. Med. 2019; 12: 65-71

\section{Wstęp}

Obserwowane w wielu krajach wysoko rozwiniętych zjawiska demograficzne, takie jak: starzenie się społeczeństw, ruchy migracyjne, a także pojawianie się nowych czynników zakaźnych przenoszonych drogą przetoczeń, wpływają negatywnie na liczbę krwiodawców i zasoby krwi i jej składników przeznaczonych do celów klinicznych. W krajach należących do Rady Europy średni wskaźnik liczby krwiodawców w przeliczeniu na 1000 mieszkańców obniżył się w latach 2008-2011 z 29,0 do 25,0 [1]. W Polsce w 2017 roku analogiczna wartość wynosiła 15,30 (w 2016 r. - 15,51) [2]. Jednym z działań podejmowanych w celu poprawy sytuacji jest dążenie do zwiększenia liczby krwiodawców, między innymi poprzez dopuszczenie do krwiodawstwa osób, które były wcześniej dyskwalifikowane, na przykład $z$ powodu rozpoznawanych zaburzeń genetycznych, niemających bezpośredniego wpływu na jakość krwi pobieranej krwi. Działanie takie dotyczy w szczególności osób $z$ rozpoznaną hemochromatozą pierwotną $(\mathrm{HH}$, hereditary hemochromatosis), leczonych przy zastosowaniu krwioupustów, zwłaszcza nosicieli defektywnego genu i pacjentów bez obecności zmian narządowych.

Krew uzyskiwana podczas krwioupustów od pacjentów $z$ HH jest obecnie często niszczona, co eliminuje potencjalnie bogate źródło składników krwi i produktów krwiopochodnych. Od czasu opisania molekularnych patomechanizmów HH można było jednak przyjąć założenie, że krew pobierana od osób $z$ hemochromatozą nie stanowi zagrożenia dla biorców. Przeprowadzane od lat lecznicze upusty krwi od osób z HH zaczęto zatem brać pod uwage jako potencjalne źródło krwi do celów krwiolecznictwa [3].

\section{Hemochromatoza — historia}

W 1865 roku francuski lekarz Armand Trousseau opisał zespół chorobowy, na który składały się: marskość wątroby, cukrzyca i brązowa pigmentacja skóry, natomiast w 1889 roku niemiecki lekarz patolog Friedrich von Recklinghausen po raz pierwszy zastosował dla tej choroby określenie „hemochromatoza” [4, 5]. W 1935 roku Joseph H. Sheldon, brytyjski geriatra, opublikował monografię omawiająca 311 przypadków hemochromatozy opisanych do tej pory w literaturze światowej [6]. Sheldon określił hemochromatozę jako dziedziczne zaburzenie, charakteryzujące się nadmiernym gromadzeniem żelaza, prowadzące ostatecznie do uszkodzenia tkanek. Należy podkreślić, że te wnioski — trafne w świetle obecnej wiedzy — Sheldon sformułował, nie korzystając $z$ dostępnych obecnie technik nowoczesnej medycyny. Molekularne patomechanizmy HH (mutacja genu HFE) zostały następnie opisane przez Federa i wsp. dopiero w 1996 roku [7]. 


\section{Hemochromatoza pierwotna — patogeneza i epidemiologia}

Hemochromatoza jest ogólnoustrojową chorobą spowodowaną nadmiernym gromadzeniem żelaza, przy czym oprócz hemochromatozy pierwotnej (dziedzicznej) wyróżnia się także postacie wtórne (syderozy wtórne) i mieszane. Przedmiotem zainteresowania krwiodawstwa i krwiolecznictwa są jednak zasadniczo tylko pacjenci $z$ hemochromatozą pierwotną.

Hemochromatoza pierwotna jest chorobą uwarunkowaną genetycznie. Dziedziczona jest w sposób autosomalny recesywny, zatem objawy choroby występują u homozygot. Jakkolwiek poszczególne formy hemochromatozy pierwotnej są fenotypowo zbliżone, u ich podłoża leżą różne defekty genetyczne - najczęściej mutacje genu HFE (High Fe) zlokalizowanego na krótkim ramieniu chromosomu 6 [8]. U większości chorych (ponad 80\%) obecna jest mutacja C282Y, natomiast u pozostałych chorych w tym samym genie stwierdzano inną mutację - H63D. W Europie nosiciele najczęstszej mutacji (C282Y) genu HFE, wywołującej $\mathrm{HH}$, stanowią zależnie od regionu, od $0 \%$ populacji w Europie Południowej do 12,5\% w Irlandii. W Polsce wskaźnik ten wynosi 4,4\%, przy czym szacuje się, że u 10-33\% homozygot C282Y rozwiną się objawy kliniczne $\mathrm{HH}$ (penetracja kliniczna wynosi średnio $13,5 \%$, ok. $28 \%$ u mężczyzn i tylko $1 \%$ u kobiet) [9]. Kobiety wykazują objawy kliniczne hemochromatozy rzadziej niż mężczyźni, prawdopodobnie w związku ze stratami żelaza $\mathrm{w}$ następstwie miesiączek oraz $\mathrm{w}$ przebiegu ciąży.

W przebiegu wszystkich postaci HH wspólnym patomechanizmem jest niedostateczna synteza przez wątrobę lub nieprawidłowa czynność peptydowego hormonu hepcydyny, odgrywającego kluczową rolę w regulacji homeostazy żelaza $\mathrm{w}$ organizmie ludzkim. W konsekwencji w przebiegu HH dochodzi do zwiększonego wchłaniania żelaza, a w następstwie - do jego gromadzenia $\mathrm{w}$ wątrobie, trzustce, sercu, stawach i innych tkankach. Rezultatem są ogólnoustrojowe powikłania (cukrzyca, artropatia, marskość wątroby, rak wątrobowo-komórkowy, niewydolność krążenia, zaburzenia hormonalne). Choroba ma charakter postępujący:

- do 20. roku życia cechuje się zazwyczaj jedynie niewielkim zwiększeniem zapasów żelaza w tkankach;

- w wieku 20-40 lat dochodzi już do przeciążenia organizmu żelazem, jednak jeszcze bez objawów chorobowych;
— powyżej 40. roku życia u chorych nieleczonych dochodzi do uszkodzenia narządów i wystąpienia objawów klinicznych (> $20 \mathrm{~g}$ żelaza w tkankach, norma: 4-5 g).

Rokowanie u chorych nieleczonych jest złe. Bez leczenia 5-letnie przeżycie od wystąpienia objawów klinicznych wynosi około $33 \%$, a bezpośrednią przyczyną zgonu jest najczęściej niewydolność serca, niewydolność wątroby lub rak wątrobowokomórkowy [9]. Bardzo istotne jest zatem wczesne ustalenie rozpoznania (na podstawie wczesnych objawów lub niekiedy wywiadu rodzinnego) i rozpoczęcie we właściwym czasie skutecznego leczenia krwioupustami.

\section{Hemochromatoza - leczenie}

W 1950 roku Davis opisał zastosowanie w terapii hemochromatozy powtarzanych krwioupustów [10]. Obecnie metodą leczenia $z$ wyboru są upusty $500 \mathrm{ml}$ krwi wykonywane początkowo co 1-2 tygodnie w celu eliminacji nadmiaru nagromadzonego już w organizmie żelaza $(500 \mathrm{ml} \mathrm{krwi}$ zawiera około $250 \mathrm{mg}$ żelaza). Jest to tak zwana faza indukcji. Po zmniejszeniu stężenia ferrytyny poniżej $50-100 \mathrm{ng} / \mathrm{ml}$ upusty wykonuje się rzadziej, zazwyczaj co 2-4 miesiące (leczenie podtrzymujące) [9]. Nie przeprowadzono dotychczas badań kontrolowanych $z$ randomizacją dotyczących skuteczności takiego postępowania. Aktualne wytyczne opierają się w znacznej mierze na wynikach badań obserwacyjnych oraz na opiniach ekspertów [11].

\section{Obawy związane $z$ oddawaniem krwi przez osoby z hemochromatozą}

Obawy związane $z$ oddawaniem krwi do celów klinicznych przez osoby z $\mathrm{HH}$ dotyczą przede wszystkim dodatkowych czynników wpływających na bezpieczeństwo tak pozyskanych składników krwi, a także problemów organizacyjnych oraz kosztów [12]. Zgłaszane są między innymi obawy, że przeciążenie organizmu dawcy żelazem wiąże się ze zwiększonym ryzykiem wystąpienia zakażeń bakteryjnych (zwłaszcza Vibrio sp., Salmonella $s p$., Yersinia sp.), a także wątpliwości dotyczące potencjalnie toksycznego działania obecnego w ich osoczu żelaza niezwiązanego $z$ transferryną (NTBI, non-transferrin-bound serum iron) [13]. Zagrożenia te mają jednak, według aktualnych opinii, charakter przede wszystkim teoretyczny, a ich znaczenie w praktyce klinicznej jest uznawane za znikome [11]. 
Podnoszone są również wątpliwości natury etycznej dotyczące motywacji krwiodawców $\mathrm{HH}$, którzy najczęściej nie kierują się względami altruistycznymi, lecz przede wszystkim troską o własne zdrowie. Zgłaszane są w związku $z$ tym obawy, że w krajach, gdzie za lecznicze upusty krwi trzeba płacić, osoby z HH mogą ukrywać czynniki ryzyka związane $z$ chorobami zakaźnymi przenoszonymi drogą przetoczeń (TTI, transfusion-transmissible infection), aby móc dokonać zabiegu za darmo [14].

\section{Wytyczne towarzystw naukowych i przepisy prawne}

Kilka dużych towarzystw naukowych opublikowało wytyczne dopuszczające wykorzystywanie krwi pobranej od dawców HH do celów terapeutycznych, jednocześnie jednak wiele organizacji nie zajęło stanowiska w tej sprawie. Ważnym zdarzeniem w kontekście krwiodawstwa było dopuszczenie w Stanach Zjednoczonych osób z HH do oddawania krwi przez Food and Drug Administration (FDA) w 2001 roku. Warunkiem było wdrożenie alternatywnego programu bezpłatnych krwioupustów dla osób z HH [15]. Postępowanie wobec tej grupy potencjalnych krwiodawców jest jednak w Stanach Zjednoczonych zróżnicowane. Krwi od dawców HH nie pobierają między innymi centra pozostające pod nadzorem Amerykańskiego Czerwonego Krzyża [11].

Według wytycznych Światowej Organizacji Zdrowia (WHO, World Health Organization) z 2012 roku pobieranie krwi od dawców HH jest dopuszczalne pod warunkiem spełnienia przez nich wszystkich pozostałych kryteriów kwalifikacyjnych, przy czym w przypadkach, gdy jeżeli ze względów klinicznych konieczne jest zastosowanie krótszej niż w przypadku pozostałych krwiodawców przerwy między kolejnymi donacjami, należy zastosować w tym celu specjalne rozwiązania [16].

Zgodnie $z$ przepisami obowiązującymi aktualnie w Polsce (Rozporządzenie Ministra Zdrowia $z$ dnia 11 września 2017 r. w sprawie warunków pobierania krwi od kandydatów na dawców krwi i dawców krwi), o możliwości oddania krwi przez osoby z $\mathrm{HH}$ oraz częstotliwości kolejnych donacji decyduje lekarz w jednostce organizacyjnej publicznej służby krwi, w porozumieniu $z$ lekarzem prowadzącym leczenie hemochromatozy. Osoby z HH nie mogą oddawać krwi w czasie występowania objawów choroby, a także $\mathrm{w}$ trakcie stosowanego leczenia innego niż krwioupusty [17].

\section{Doświadczenia dotyczące oddawania krwi przez osoby $z$ hemochromatozą w różnych krajach}

Instytucja Narodowe Instytuty Zdrowia (NIH, National Institutes of Health), działająca w Stanach Zjednoczonych, stosuje pobieranie krwi od dawców HH do celów leczniczych i do badań naukowych, poczynając od 2001 roku [18]. Obecnie dawcy z HH stanowią około 7\% ogółu krwiodawców, jednak dostarczają w przybliżeniu 11\% donacji krwi alogenicznej. W 16-letnim okresie doświadczeń NIH u dawców HH nie stwierdzono przypadków serokonwersji do zakaźnych czynników chorobotwórczych przenoszonych drogą przetoczeń [19]. Ta obserwacja jest o tyle zrozumiała, że osoby z HH zazwyczaj oddają krew systematycznie przez dłuższy czas, a zgodnie $z$ dotychczasowymi obserwacjami u dawców wielokrotnych zakażenia TTI stwierdza się rzadziej niż u pierwszorazowych [20].

W 2013 roku Pauwels i wsp. opublikowali wyniki ankiety o zasięgu ogólnoświatowym, opracowanej $z$ myślą o porównaniu możliwości oddawania krwi do celów leczniczych przez osoby z $\mathrm{HH}$ zamieszkałe w różnych krajach [12]. $\mathrm{W}$ tym celu opracowano internetowy formularz, który następnie skierowano do 44 przedstawicieli służby krwi w 41 państwach na 5 kontynentach. Zagadnienia poruszone $\mathrm{w}$ ankiecie przedstawiono pokrótce poniżej:

1. Grupy osób akceptowane jako dawcy krwi, przy założeniu, że wszystkie inne wymagania dotyczące oddawania krwi zostaną spełnione:

- bezobjawowi nosiciele defektywnego genu o normalnej zawartości żelaza w organizmie,

- bezobjawowi nosiciele defektywnego genu o zwiększonej zawartości żelaza w organizmie,

- pacjenci bezobjawowi w fazie leczenia podtrzymującego,

- pacjenci objawowi w fazie indukcji,

- pacjenci objawowi w fazie leczenia podtrzymującego

- żadne $\mathrm{z}$ powyższych.

2. Powód akceptacji/odrzucenia osób HH jako krwiodawców

- przepisy prawne,

- regulacje wewnętrzne,

- opinie ekspertów/opinia własna/preferencje,

- względy etyczne,

- inne czynniki.

3. Udział osób z udokumentowaną mutacją HFE w ogólnej puli krwiodawców.

4. Częstość donacji. 
5. Lekarz decydujący o możliwości oddawania krwi przez dawcę $\mathrm{HH}$ :

- lekarz prowadzący,

- lekarz kwalifikujący krwiodawców,

- zarówno lekarz prowadzący, jak kwalifikujący krwiodawców,

- żaden $z$ ww. lekarzy.

6. Miejsce donacji (centra krwiodawstwa, ekipy wyjazdowe).

7. Wykonywane badania laboratoryjne.

Formularz wypełniło 35 adresatów z 33 krajów (80\%); w 24 przypadkach (69\%) udzielili oni odpowiedzi twierdzącej na pytanie dotyczące możliwości oddawania krwi przez osoby $z$ hemochromatozą i/lub nosicieli defektywnego genu, przy czym:

- w 7/35 ośrodków (20\%) krew pobierano zarówno od nosicieli, jak i od pacjentów z $\mathrm{HH}$ w fazie indukcji i leczenia podtrzymującego (m.in. RPA, Kanada [Ottawa], Australia, Izrael);

— w 6/35 (17\%) — wyłącznie od nosicieli i bezobjawowych pacjentów (Czechy, Kanada [Montreal], Austria, Norwegia, Irlandia, Szkocja);

— w 11/35 (31\%) — od żadnej z wymienionych grup (10 krajów europejskich i Hong Kong).

Odpowiedzi 11 pozostałych ankietowanych ośrodków nie były na tyle ściśle sprecyzowane, by można je było jednoznacznie zaklasyfikować.

Najczęściej stosowaną postawą akceptacji/ /odrzucenia dawców HH były opinie ekspertów i własne preferencje (20 ośrodków) oraz regulacje wewnętrzne (18 ośrodków); jedynie w 3 ośrodkach opierano się wyłącznie na przepisach prawnych.

Udział dawców $z$ hemochromatozą/nosicieli w ogólnej puli krwiodawców wynosił:

- w 12 ośrodkach < 1\%;

- w 5 ośrodkach - 1-5\%;

- w pozostałych nie został jednoznacznie określony.

W 33\% ośrodków akceptujących dawców $\mathrm{HH}$ dopuszczalna częstość donacji była większa niż w przypadku pozostałych krwiodawców. W $68 \%$ ośrodków mogli oni oddawać krew zarówno w centrach krwiodawstwa, jak i w czasie ekip wyjazdowych.

W większości ośrodków akceptujących dawców HH (83\%) możliwość oddawania krwi przez osoby $z$ hemochromatozą i/lub nosicieli była uzależniona od uzyskania akceptacji lekarza prowadzącego (zazwyczaj internisty lub hepatologa) i/albo lekarza kwalifikującego krwiodawców. Sytuację utrudniał niewątpliwe fakt, że ze względu na niespecyficzność symptomatologii oraz zróżnicowanie objawów choroby pacjenci mogą być leczeni przez lekarzy różnych specjalności (w tym diabetologów, kardio- logów, gastroenterologów, neurologów, ortopedów, transplantologów).

Wszystkie ankietowane ośrodki przeprowadzają rutynowo badania stężenia hemoglobiny, natomiast żaden nie wykonuje genetycznych badań przesiewowych w kierunku mutacji HFE. Rzadko (jedynie w 7 ośrodkach) są wykonywane badania dotyczące stanu gospodarki żelazem (stężenia ferrytyny, wysycenia transferyny żelazem).

Należy podkreślić, że zasady postępowania wobec tej grupy potencjalnych krwiodawców różnią się nie tylko pomiędzy poszczególnymi krajami, ale niekiedy również pomiędzy ośrodkami znajdującymi się na terenie tego samego kraju (np. w Szwecji, Kanadzie i w Stanach Zjednoczonych). Podstawowym wnioskiem uzyskanym dzięki ww. badaniu ankietowemu jest występowanie znacznego zróżnicowania, jeśli chodzi o stosunek służby krwi do osób $z$ hemochromatozą i nosicieli defektywnego genu. Podkreślono zatem potrzebę opracowania jednolitych zasad postępowania na podstawie wyników dostępnych badań.

Ważnym przyczynkiem do poszerzenia wiedzy na temat możliwości pobierania krwi do celów leczniczych od dawców $\mathrm{z}$ HH wydaje się zakończone niedawno opracowanie autorów australijskich. W opublikowanej w 2016 roku pracy Hoad i wsp. przedstawili wyniki zakrojonego na bardzo szeroką skalę retrospektywnego badania oceniającego ryzyko powikłań zakaźnych towarzyszącego stosowania w krwiolecznictwie krwi pobranej od dawców $z \mathrm{HH}$ (w Australii pobieranie krwi od dawców z HH zostało wprowadzone już w 1998 r.) [21]. Badanie to obejmowało wszystkie donacje krwi pobrane w okresie 3 lat w placówkach Australijskiego Czerwonego Krzyża. Analiza dotyczyła zarówno „Zwyczajnych” krwiodawców honorowych (2,5 miliona donacji od ponad 460000 osób), jak i od dawców HH (ponad 100000 donacji od 12000 osób). Badanie obejmowało zarówno osoby z HH przechodzące fazę indukcji leczenia, tj. eliminacji nadmiaru nagromadzonego żelaza, jak i będące już w trakcie leczenia podtrzymującego. Oceniano między innymi wyniki badań bakteriologicznych, badań na obecność markerów chorób zakaźnych przenoszonych drogą przetoczeń, jak również częstość zgłoszeń o zachorowaniach dawców na choroby zakaźne, które wpłynęły już po odbyciu donacji. Dawcy HH musieli spełniać kryteria stosowane wobec ogółu krwiodawców, jednak darmowe krwioupusty zapewniono również osobom, które nie zakwalifikowały się do oddania krwi przeznaczonej do celów leczniczych. Celem tego postępowania było wyeliminowanie ryzyka zatajenia przez 
dawców istotnych danych związanych $z$ ryzykiem przeniesienia TTI.

Jak stwierdzono, częstość występowania TTI była znacząco niższa w przypadku donacji pochodzących od osób z HH niż u innych honorowych krwiodawców (odpowiednio 8,4 i 21,6 na 100000 donacji). Częstość wykrywania zakażeń bakteryjnych, jak również częstość zgłaszania zachorowań już po donacji była w obu grupach zbliżona.

Autorzy podkreślają również znaczenie faktu, że dawcy HH są znacznie mniej narażeni na związany $\mathrm{z}$ donacją niedobór żelaza i jego następstwa, które stanowią nieraz znaczny problem u „zwyczajnych" krwiodawców. Co więcej, dawcy $\mathrm{HH}$ to $\mathrm{w}$ większości mężczyźni $\mathrm{w}$ średnim wieku, u których częstość występowania niektórych typowych niepożądanych reakcji związanych $z$ donacją (reakcja wazowagalna) jest zazwyczaj mniejsza niż u osób młodych. Autorzy stwierdzają zatem, że dawcy $z \mathrm{HH}$ stanowią akceptowalne i bezpieczne źródło krwi przeznaczonej do celów leczniczych.

Pozytywne wyniki badań nad możliwością oddawania krwi przez dawców HH opisują również autorzy $z$ innych krajów, w tym ze Stanów Zjednoczonych [19], Norwegii [22] i z Wielkiej Brytanii [23].

Rzeczywisty udział nosicieli defektywnego genu w puli krwiodawców jest jednak prawdopodobnie niedoceniany. Wiele osób nie zdaje sobie sprawy ze swojego genetycznego obciążenia i nie wykazuje fizycznych oznak przeciążenia żelazem lub oddaje krew pomimo rozpoznania choroby. Opublikowane w 2001 roku wyniki analizy anonimowej ankiety przeprowadzonej wśród krwiodawców kilku ośrodków amerykańskich wykazały znaczący udział chorych na hemochromatozę, przy czym $89 \%$ z nich oddawało krew w centrach nieakceptujących $z$ założenia tej grupy osób jako krwiodawców [24]. Prawdopodobną przyczyną był brak edukacji krwiodawców lub niedoskonałości przeprowadzanych przez te ośrodki badań przeglądowych.

\section{Podsumowanie}

Hemochromatoza pierwotna jest uwarunkowaną genetycznie chorobą, której następstwem jest zespół przeciążenia żelazem. Najbardziej efektywny sposób leczenia opiera się na wykonywaniu częstych krwioupustów w celu eliminacji $z$ organizmu nadmiaru żelaza. W wielu centrach krwiodawstwa na całym świecie nie stosuje się obecnie pobierania krwi od dawców HH do celów klinicznych, tracąc w ten sposób dodatkowe źródło składników krwi i produktów krwiopochodnych. Najczęściej wymieniane obawy to zwiększone ryzyko zakażenia, a także wątpliwości natury etycznej związane $z$ dobrowolnością donacji.

W świetle aktualnie dostępnych danych brakuje przekonujących dowodów na to, że krew od osób HH stwarza większe zagrożenie dla biorców niż krew pochodząca od pozostałych dawców. Biorąc jednak pod uwagę wyżej opisane znaczne zróżnicowanie zasad postępowania i opinii w różnych krajach, wskazane wydaje się opracowanie — na podstawie wyników dotychczasowych badań — optymalnych zasad postępowania, które byłyby korzystne dla osób $z$ hemochromatozą i/lub nosicieli defektywnego genu, a przy tym przyczyniły się do zwiększenia światowych zasobów krwi.

\section{Piśmiennictwo}

1. Pogłód R, Rosiek A, Grabarczyk P, et al. Charakterystyka podstawowych wskaźników dotyczących krwiodawstwa i krwiolecznictwa w Europie - aktualne wyzwania i działania. Journal of Transfusion Medicine. 2015; 8(2): 60-77.

2. Rosiek A, Tomaszewska A, Lachert E, et al. Działalność jednostek organizacyjnych służby krwi w Polsce w 2017 roku. Journal of Transfusion Medicine. 2018; 4(11): 113-130.

3. Barton JC, Grindon AJ, Barton NH, et al. Hemochromatosis probands as blood donors. Transfusion. 1999; 39(6): 578-585, doi: 10.1046/j.1537-2995.1999.39060578.x, indexed in Pubmed: 10378837.

4. Trousseau A. Glycosurie, diabète sucré. Clinique médicale de l'Hôtel-Dieu de Paris, Vol. 2, 2nd edn. Balliere, Paris 1865: 663.

5. von Recklinghausen FD, Über Hamochromatose. Tagebl Versamml Natur Ärzte Heidelberg. 1889; 62: 324.

6. Sheldon JH. Haemochromatosis. Oxford University Press, London 1935.

7. Feder JN, Gnirke A, Thomas W, et al. A novel MHC class I-like gene is mutated in patients with hereditary haemochromatosis. Nat Genet. 1996; 13(4): 399-408, doi: 10.1038/ng0896-399, indexed in Pubmed: 8696333.

8. Weiss G. Genetic mechanisms and modifying factors in hereditary hemochromatosis. Nat Rev Gastroenterol Hepatol. 2010; 7(1): 50-58, doi: 10.1038/nrgastro.2009.201, indexed in Pubmed: 19918260.

9. Mach T. Hemochromatoza. W: Gajewski P. i wsp. (red.). Interna Szczeklika. Medycyna Praktyczna, Kraków 2018: 1185-1189.

10. Davis WD, Arrowsmith WR. The effect of repeated bleeding in Hemochromatosis. J Lab Clin Med. 1950; 36(5): 814-815, indexed in Pubmed: 14784678.

11. Winters AC, Tremblay D, Arinsburg S, et al. Reassessing the safety concerns of utilizing blood donations from patients with hemochromatosis. Hepatology. 2018; 67(3): 1150-1157, doi: 10.1002/hep.29521, indexed in Pubmed: 28902419.

12. Pauwels NS, De Buck E, Compernolle V, et al. Worldwide policies on haemochromatosis and blood donation: a survey among blood services. Vox Sang. 2013; 105(2): 121-128, doi: 10.1111/ vox.12038, indexed in Pubmed: 23663183.

13. De Buck E, Pauwels NS, Dieltjens T, et al. Is blood of uncomplicated hemochromatosis patients safe and effective for 
blood transfusion? A systematic review. J Hepatol. 2012; 57(5): 1126-1134, doi: 10.1016/j.jhep.2012.04.040, indexed in Pubmed: 22659521.

14. Pennings G. Demanding pure motives for donation: the moral acceptability of blood donations by haemochromatosis patients. J Med Ethics. 2005; 31(2): 69-72, doi: 10.1136/jme.2002.001271, indexed in Pubmed: 15681668.

15. U.S. Department of Health and Human Services, Food and Drug Administration, Center for Biologics Evaluation and Research (CBER). Guidance for Industry: Variances for Blood Collection from Individuals with Hereditary Hemochromatosis. http://academy.gmp-compliance.org/guidemgr/files/HEMCHROM.PDF. [Online] [zacytowano: 18 04.2019].

16. World Health Organization. Blood donor selection: guidelines on assessing donor suitability for blood donation, 2012.

17. Rozporządzenie Ministra Zdrowia $z$ dnia 11 września 2017 r. w sprawie warunków pobierania krwi od kandydatów na dawców krwi i dawców krwi. (Dz. U. z 2017 r. poz. 1741).

18. West KA, Eder AF. Accepting hereditary hemochromatosis blood donors: ask not why, ask why not. Transfusion. 2016; 56(12): 2907-2909, doi: 10.1111/trf.13919, indexed in Pubmed: 27933629 .

19. Leitman SF, Browning JN, Yau YuY, et al. Hemochromatosis subjects as allogeneic blood donors: a prospective study. Transfusion.
2003; 43(11): 1538-1544, doi: 10.1046/j.1537-2995.2003.00570.x, indexed in Pubmed: 14617312.

20. Zou S, Dorsey KA, Notari EP, et al. Prevalence, incidence, and residual risk of human immunodeficiency virus and hepatitis $\mathrm{C}$ virus infections among United States blood donors since the introduction of nucleic acid testing. Transfusion. 2010; 50(7): 1495-1504, doi: 10.1111/j.1537-2995.2010.02622.x, indexed in Pubmed: 20345570.

21. Hoad V, Bentley P, Bell B, et al. The infectious disease blood safety risk of Australian hemochromatosis donations. Transfusion. 2016; 56(12): 2934-2940, doi: 10.1111/trf.13802, indexed in Pubmed: 27662424.

22. Røsvik AS, Ulvik RJ, Wentzel-Larsen T, et al. Blood donors with hereditary hemochromatosis. Transfusion. 2010; 50(8): 1787-1793, doi: 10.1111/j.1537-2995.2010.02627.x, indexed in Pubmed: 20345568.

23. Marrow B, Clarkson J, Chapman CE, et al. Facilitation of blood donation amongst haemochromatosis patients. Transfus Med. 2015; 25(4): 239-242, doi: 10.1111/tme.12182, indexed in Pubmed: 25800958

24. Sanchez AM, Schreiber GB, Bethel J, et al. Retrovirus Epidemiology Donor Study (REDS). Prevalence, donation practices, and risk assessment of blood donors with hemochromatosis. JAMA. 2001; 286(12): 1475-1481, doi: 10.1001/jama.286.12.1475, indexed in Pubmed: 11572740. 